\title{
AN APPROACH TO ESTIMATE THE CLOTTING TIME OF MEASURING THE ACTIVITY OF PEPSIN
}

\author{
${ }^{1}$ Arora Neha*, ${ }^{2}$ Inderjit Singh, ${ }^{3}$ Monish Sharma, ${ }^{4}$ Garg Tarun \\ ${ }^{l}$ Department of Quality Assurance, I.S.F. College of Pharmacy, Moga, Punjab \\ ${ }^{2}$ Department of Pharmaceutical Analysis, I.S.F. College of Pharmacy, Moga, Punjab \\ ${ }^{3}$ Department of Quality Assurance, Seth G.L.Bihani S.D. College of Tech. Edu., Sriganganagar \\ ${ }^{4}$ Department of Pharmaceutics, Seth G.L.Bihani S.D. College of Tech. Edu., Sriganganagar
}

\section{INTRODUCTION}

Pepsin is aspartic proteneases. Pepsin is most active in acidic environments between $37^{\circ} \mathrm{C}$ and $42^{\circ} \mathrm{C}$ [1,2]. Accordingly, its primary site of synthesis and activity is the stomach ( $\mathrm{pH} 1.5$ to 2). Pepsin exhibits maximal activity at $\mathrm{pH} 2.0$ and is inactive at $\mathrm{pH} 6.5$ and above, however pepsin is not fully denatured or irreversibly inactivated until $\mathrm{pH}$ 8.0. Therefore pepsin in solution of up to $\mathrm{pH} 8.0$ can be reactivated upon re-acidification [3].

\section{MATERIALS AND METHOD}

To prepare substrate solution of milk powder, $12 \mathrm{~g}$ dry milk powder was added in $94 \mathrm{ml}$ of $\mathrm{CaCl}_{2}$ son after that it was stirred magnetically for 20-30 min and makeup $100 \mathrm{ml}$ with $0.01 \mathrm{M} \mathrm{CaCl}_{2}$. Than it was distributed in 10 -ml portions in separate test tubes and keep them at $30 \pm 0.2^{\circ}$ for at least $10 \mathrm{~min}$, but not more than $1 \mathrm{~h}$. To prepare the enzyme dilutions, introduce $2 \mathrm{ml}$ and $4 \mathrm{ml}$ respectively of $1.25 \mathrm{M}$ sodium acetate buffer $\mathrm{pH} 5.7$ was added in $50 \mathrm{ml}$ or $100 \mathrm{ml}$ flask, add distilled water was added to two-thirds of the volume of the flask and pipet accurately measured aliquots of the enzyme sample (dissolve, if powdered), and the reference enzyme, dilute to volume. To obtain the desired dilutions (about 1:5,000 strength, arrived at by diluting original sample solution between 25 and 200 fold), distribute $1-\mathrm{ml}$ aliquots of each dilute enzyme solution in test tubes at $(18 \times 250 \mathrm{~mm})$ and incubate at $30 \pm 0.2^{\circ}$. To start the reaction, substrate solution contained in one test tube was poured into that containing the dilute enzyme and starts concomitantly a stop watch and mix the test solution twice by rapid inversion of the test tube and keep in a slanted position in the water bath kept at $30 \pm 0.2^{\circ}$. Rotate the test tube slowly by hand until the first clots are observed whereupon the watch is stopped and the time is recorded to the nearest $0.1 \mathrm{sec}$ [1,2].

\section{Determination of clotting time}

Plot the clotting times obtained with enzyme dilutions being assayed and that with the reference standard against the dilution factors employed. Straight lines are obtained for clotting times between 50 and $300 \mathrm{sec}$.

\section{RESULT}

Clotting reaction: clotting time of enzyme -substrate reaction which have $40 \mathrm{mg} / \mathrm{ml}$ to $120 \mathrm{mg} / \mathrm{ml}$ conc of enzyme decreased with increased concentration of enzyme, showed decreased clotting time.( Table:1) Minimum clotting time was obsereved at $120 \mathrm{mg} / \mathrm{ml}$ concentration of enzyme.(Figure:1)

Table: 1 clotting time on various concentration of enzyme

\begin{tabular}{|l|l|l|}
\hline Pepsin.Concentration $(\mathrm{mg} / \mathrm{ml})$ & $\begin{array}{l}\text { Initial clotting time } \\
(\mathrm{min})\end{array}$ & $\begin{array}{l}\text { Final clotting time } \\
(\mathrm{min})\end{array}$ \\
\hline 120 & $1: 20$ & $2: 17$ \\
\hline 100 & $2: 20$ & $2: 52$ \\
\hline 80 & $3: 00$ & $3: 54$ \\
\hline 60 & $4: 40$ & $5: 24$ \\
\hline 40 & $6: 00$ & $7: 24$ \\
\hline
\end{tabular}




\section{time}

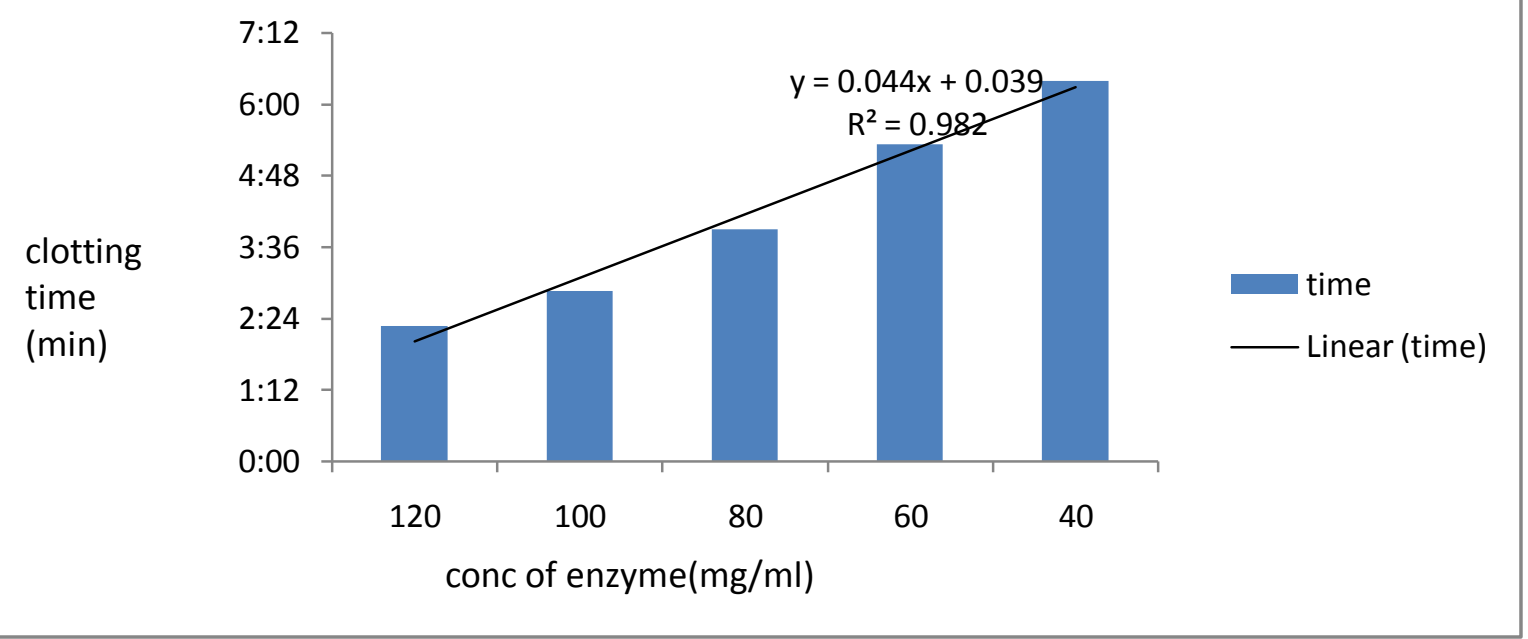

Figure:1 Effect of enzyme concentration on clotting time

\section{CONCLUSION}

Clotting time of enzyme substrate reaction is decreased with increase concentration of enzyme indicate the active form of enzyme present in it, and other soluble form does not give the clot.

\section{REFERENCES}

1. M. Castilo, Predicting cutting and clotting time of coagulated goat milk, International dairy journal,10, 2000,551-562.

2. M. Bergmann, W.F. Ross, J. Biol. Chem., 111,1935,659.

3. M. Bergmann, W.F. Ross, J. Biol. Chem., 114,1936,717. 